\title{
ANALISA HUKUM DISKRESI POLISI PADA UPAYA PEMBERANTASAN TINDAK PIDANA NARKOTIKA DI POLRES BLITAR KOTA
}

\author{
Supriyanto, Mahasiswa Fakultas Hukum Universitas Islam Balitar, Blitar, Indonesia, E-mail: \\ Rian_ashter@yahoo.co.id
}

\begin{abstract}
Abstrak
Kepolisian Negara Republik Indonesia memiliki kewenangan yang sangat luas dalam menegakan hukum dan menjamin keamanan serta ketertiban masyarakat. Oleh karena itu Polisi diberi kewenangan melakukan diskresi Kepolisian, yakni sebuah konsep pemberian otoritas untuk melakukan tindakan berdasarkan pertimbangan hati nurani polisi yang sedang bertugas ataupun pertimbangan institusi Kepolisian.

Melalui penelitian normatif dilengkapi dengan data sekunder penelitian di Polres Blitar Kota maka diperoleh hasil penelitian bahwa diskresi polisi sebagai tindakan pihak yang berwenang berdasarkan hukum untuk bertindak pasti atas dasar situasi dan kondisi menurut pertimbangan dan keputusan nuraninya sendiri sesuai Undang-Undang Nomor 2 Tahun 2002 tentang Kepolisian Republik Indonesia. Atas kewenangan polisi melakukan penyidikan terhadap semua tindak pidana, maka pelaksanaan diskresi harus dilakukan dengan pertimbangan-pertimbangan yang jelas, yang bertujuan untuk menghindari munculnya penilaian negatif dari masyarakat bahwa penerapan diskresi kepolisian dianggap sebagai permainan pihak kepolisian untuk memperoleh keuntungan materi dari pihak-pihak yang berperkara agar penerapan diskresi kepolisian tidak dipandang sebagai alat rekayasa dari aparat kepolisian untuk memperoleh keuntungan pribadi, sehingga penerapannya harus dilandasi dasar hukum yang kuat. Terkait hal tersebut, perwujudan Diskresi Polisi di Polres Blitar Kota pada upaya pemberantasan tindak pidana narkotika, bersifat individual dan institusional.
\end{abstract}

Kata Kunci: Diskresi, Polisi, Tindak Pidana Narkotika

\section{PENDAHULUAN}

\section{Latar Belakang}

Narkotika merupakan obat-obatan terlarang yang dapat merusak fikiran, fisik, mental, emosi maupun sikap seseorang dalam bermasyarakat. obat-obatan ini pada awalnya memang mampu menenangkan fikiran. namun dapat menimbulkan kecanduan bagi orang-orang yang sering mengkonsumsinya. Narkotika sebenarnya memiliki manfaat tersendiri bagi dunia medis namun setiap penggunaannya memiliki takaran yang ditentukan oleh dokter. Narkotika sangat berguna sebagai obat bius bagi pasien yang akan menjalani operasi bedah serta sebagai obat penenang. Namun semakin maju perkembangan zaman, narkotika justru tersebar bebas di luar dunia medis bahkan diperjual belikan dengan gampang dan dengan harga yang cukup fantastis.

Masalah narkotika sudah menjadi masalah serius skala nasional maupun internasional yang tidak pernah habis diberitakan setiap harinya. Bahkan dinegara Indonesia telah dibentuk sebuah undang-undang yang mengatur terkait larangan penyalahgunaan narkotika serta telah dibentuk badan hukum khusus yaitu Badan Narkotika Nasional (BNN) yang menangani hal tersebut dibantu oleh pihak kepolisian untuk menuntaskan penyalahgunaan narkotika yang telah menyebar luas di negara ini.

Lembaga kepolisian sebagai salah satu lembaga penegak hukum di Indonesia yang memiliki tujuan untuk memberikan perlindungan dan layanan kepada masyarakat. Otoritas kepolisian adalah lembaga tingkat pertama yang menangani masalah sebelum 
dibawa ke pengadilan dengan melakukan penyelidikan terhadap suatu masalah. ${ }^{1}$ Kepolisian memiliki wewenang khusus terkait tugasnya melakukan penyelidikan atas sebuah kasus yang tengah beredar terkait adanya laporan dari rakyat tentang adanya narkotika yang semakin berkembang di masyarakat.

Hal ini seiring dengan kebutuhan masyarakat yang semakin kompleks, dimana masyarakat ingin berperkara secara cepat, takut dan malas menyelesaikan perkaranya di jalur litigasi atau pengadilan, bahkan masyarakat mencoba mendiskriminasikan perkara tertentu ${ }^{2}$. Seperti halnya fakta hukum yang masih terjadi hingga sekarang ini adanya budaya ewuh pakewuh, dan adanya penegakan hukum yang masih diskriminatif. Tersangka korupsi dan pencuri sandal akan mendapat perlakuan yang berbeda. Tersangka yang memiliki status sosial tinggi akan diperlakukan secara istimewa. Penegak hukum seolah-olah hanya berpihak kepada si kaya tetapi tidak pada si miskin, bahkan hukum berpihak pada mereka yang memiliki jabatan dan koneksi dan para pejabat hukum atau akses terhadap keadilan. Sehingga polisi sebagai aparat penegak hukum serta penjaga ketertiban dan keamanan masyarakat, mempunyai peran lain yakni sebagai juru damai (arbiter) dalam penyelesaian perkara masyarakat.

Hal ini bertolak belakang dengan adanya full enforcement (penegakan hukum secara penuh). Dimana full enforcement merupakan area penegakan hukum yang dapat melindungi nilai dan prinsip kepastian hukum secara efektif. Akan tetapi ternyata terdapat kondisi-kondisi dimana penegak hukum pidana, khususnya polisi, kadangkala diharuskan melakukan atau terpaksa melakukan kebijakan atau tindakan lain (yang seringkali disebut dengan "diskresi") yang sebenarnya tidak diharapkan. Seperti fakta hukum akhir-akhir ini yakni polisi menembak mati orang sakit jiwa ${ }^{3}$.

Ketidaklugasan POLRI menindak seluruh pelanggar hukum menunjukkan adanya penyeleksian terhadap pelanggaran-pelanggaran hukum. Penyeleksian tersebut mengakibatkan penegakan hukum bagi pelanggarnya tidaklah sama. Penyeleksian tersebut juga mengakibatkan perbedaan tindakan lanjutan terhadap pelanggar hukum. Mungkin beberapa kasus selalu atau hampir selalu ditindak, ada juga beberapa yang tidak pernah atau hampir tidak pernah ditindak, atau ada beberapa yang kadang-kadang ditindak, atau sama sekali tidak ditindak. ${ }^{4}$ Dengan kata lain POLRI melakukan seleksi dalam menegakkan hukum terhadap para pelanggarnya.

Berkaitan hal tersebut, menjadikan polisi melakukan penegakan hukum secara selektif yang menuntut untuk melakukan tindakan lain menurut penilaiannya sendiri diluar peraturan perundang-undangan (atau seringkali disebut dengan istilah

\footnotetext{
${ }^{1}$ Dianaanitakristianti.blogspot.com/2013/12/diskresi-kepolisian.html diakses pada 18 Juli 2018 pukul 19.20

${ }^{2}$ Baca kasus nenek minah dihukum 1 bulan 15 hari. Mencuri 3 buah kakao. Kamis, 19 November 2009. www.news.detik.com.

${ }^{3}$ Lihat kasus di Malang. Jawa Pos, 10 Maret 2014. Seperti yang dikatakan oleh Kapolsek Ngajum, Kabupaten Malang, AKP Sri Sugeng Waskito, diskresi boleh dilakukan dengan prosedur yang tepat. "Siapapun yang terancam jiwanya boleh melakukan tindakan diskresi kepolisian atau tindakan tanpa menunggu perintah dari atasan".

${ }^{4}$ Kenneth dkk, Police Discretion, West Publishing, Chicago, 1975, hlm. 1.
} 
"diskresi" 5 ) dalam menjalankan tugas, pokok dan fungsinya (tupoksi) untuk segera menangani perkara demi mewujudkan ketertiban masyarakat. Hal ini jelas mengindahkan tujuan hukum yang utama yakni kepastian hukum. Dimana secara tegas, dijelaskan bahwa kepastian hukum di Indonesia berbentuk tertulis dan diwujudkan dalam penormaan dalam perundang-undangan.

\section{Rumusan Masalah}

Masalah yang akan dikaji dalam penulisan ini adalah terkait :

1. Bagaimanakah diskresi polisi menurut Undang-Undang Kepolisian?

2. Apa kewenangan polisi dalam pemberantasan narkotika menurut Undang-Undang Narkotika?

3. Bagaimana perwujudan diskresi polisi pada upaya pemberantasan tindak pidana narkotika di Polres Blitar Kota?

\section{METODOLOGI PENELITIAN}

Metode penelitian yang digunakan dalam penelitian ini adalah penelitian hukum normatif.6 Penelitian yang dilakukan oleh penulis lebih ditunjukkan kepada pendekatan undang-undang dan pendekatan kasus, pendekatan undang-undang dilakukan dengan menelaah regulasi yang bersangkut paut dengan isu hukum yang sedang diteliti ${ }^{7}$, dengan rujukan utama pada UU Narkotika dan UU kepolisian. Data sekunder diperoleh dengan studi dokumen atau kepustakaan. Penelitian ini menggunakan teknik analisis logis normatif, yaitu analisis yang dilakukan berdasarkan logika dan undang-undang yang ada serta menarik kesimpulan yang telah ada.

Adapun metode pendekatan pada penelitian ini adalah :

a. Pendekatan Konseptual (conceptual approach)

Pendekatan konseptual yaitu pengkajian hukum melalui pendekatan konsep yuridis. ${ }^{20}$ Pendekatan konseptual digunakan untuk menemukan pandanganpandangan dan doktrin-doktrin yang berkembang dalam ilmu hukum. Kajian terhadap pandangan dan doktrin yang nantinya dapat ditemukan asas atau prinsip hukum yang relevan denga isu hukum.

b. Pendekatan peraturan perundang-undangan (statute approach)

\footnotetext{
${ }^{5}$ Menurut pakar hukum Administrasi Negara, Prof. Benyamin Hossein mendefinikan Diskresi sebagai kebebasan bagi seorang pejabat publik untuk mengambil keputusan menurut pertimbangannya sendiri. Pejabat eksekutif yang banyak bersentuhan dengan pelaksanaan undangundang, tidak dapat dibatasi untuk bertindak, manakala terjadi kekosongan hukum (wetvacuum) atau ada peraturan pelaksanaan undang-undang yang perlu ditafsirkan (interpertate).

${ }^{6}$ Metode penelitian hukum normatif atau metode penelitian hukum kepustakaan adalah metode atau cara yang dipergunakan didalam penelitian hukum yang dilakukan dengan cara meneliti bahan pustaka yang ada. (Soerjono Soekanto dan Sri Mamudji, Penelitian Hukum Normatif Suatu Tinjauan Singkat, Cetakan ke-11(Jakarta: PT Raja Grafindo Persada, 2009), hlm: 13-14.

${ }^{6}$ Peter Mahmud Marzuki, Penelitian Hukum, (Jakarta: Kencana Prenada Media Group, 2009) hlm: 93.)

${ }^{7}$ Peter Mahmud Marzuki, Penelitian Hukum, (Jakarta: Kencana Prenada Media Group, 2009) hlm: 93.

${ }^{20}$ Johnny Ibrahim, Metode Penelitian Hukum Normatif, (Malang : Bayumedia, 2011), hlm. 306.
} 
Pendekatan ini dilakukan dengan menelaah semua Undang-undang dan regulasi yang berkaitan dengan isu hukum melalui pengkajian hukum yakni aturan tertinggi berupa peraturan hukum positif yang berlaku yakni Undang-undang Dasar Negara Republik Indonesia Tahun 1945, peraturan perundang-undangan.

\section{PEMBAHASAN}

\section{DISKRESI POLISI MENURUT UNDANG-UNDANG KEPOLISIAN}

Kepolisian Negara Republik Indonesia memiliki kewenangan yang sangat luas dalam menegakkan hukum dan menjamin keamanan serta ketertiban masyarakat. Tugas kepolisian tersebut tidak dapat dilakukan hanya mengandalkan peraturan perundangundangan, karena undang-undang hanya memuat aturan pokok yang dalam praktik penegakannya selalu tergantung pada konteks masyarakatnya. Oleh karena itu, polisi diberi kewenangan melakukan diskresi kepolisian. Diskresi kepolisian pada adasarnya merupakan kewenangan kepolisian yang bersumber pada asas Kewajiban umum Kepolisian yaitu suatu asas yang memberikan kewenangan kepada pejabat kepolisian untuk bertindak atau tidak bertindak menurut penilainnya sendiri, dalam rangka kewajiban umumnya menjaga, memelihara ketertiban dan menjamin keamanan umum. ${ }^{8}$

Dalam kasus tindak pidana penyalahgunaan narkotika yang saat ini peredarannya semakin marak dan modus operasinya semakin beragam, polisi dituntut mengembangkan strategi penegakan hukumnya sendiri. Namun, dibalik itu perlu juga adanya suatu bentuk pengawasan dan pengendalian tindakan pemolisian tersebut agar bisa mengurangi kemungkinan terjadinya penyalahgunaan diskresi, supaya dampak negatif dari pelaksanaan diskresi itu tidak mengakibatkan ketidakadilan dalam penegakan hukum dan kemerosotan wibawa polisi. ${ }^{9}$

Manfaat diskresi dalam penanganan tindak pidana atau kejahatan adalah sebagai salah satu cara untuk membangun moral petugas kepolisian dan meningkatkan profesionalitas dan intelektualitas anggota polisi dalam menjalankan tugas dan wewenangnya secara proporsional dan memenuhi rasa keadilan, bukan atas dasar kesewenang-wenangan. ${ }^{10}$

Dalam Pasal 2 UU Nomor 2 Tahun 2002 tentang Kepolisian Republik Indonesia bahwa Fungsi Kepolisian adalah salah satu fungsi pemerintahan dibidang pemeliharaan keamanan dan ketertiban masyarakat, penegak hukum, perlindungan, pengayoman dan pelayanan kepada masyarakat. Hal tersebut dipertegas dalam passal 14 ayat (1) huruf g UU Kepolisian bahwa polisi berwenang melakukan penyidikan terhadap semua tindak pidana. Hal demikian menyatakan bahwa polisi adalah penyidik dan berwenang melakukan penyidikan tindak pidana yang sebelumnya didahului oleh tindakan penyelidikan oleh penyidik.

Pasal 16 ayat (1) Undang-undang Nomor 2 Tahun 2002 tentang Kepolisian Negara Repubik Indonesia, dalam melaksanakan tugas yang telah dirinci dalam pasal 13 dan

\footnotetext{
${ }^{8}$ https://krisnaptik.com/polri-4/hukum-kepolisian/hukum-kepolisian/, diakses pada 18 Juli 2018.

${ }^{9}$ Putu Yudha Prawira dkk, Jurnal Hukum: Diskresi Kepolisian Dalam Penyelidikan Tindak Pidana Penyalahgunaan Narkoba di Polda Jateng, 2014.

${ }^{10}$ H.R. Abdussalam. Hukum Kepolisian Sebagai Hukum Positif dalam Disiplin Hukum. Restu Agung, Jakarta. 2009, hlm. 48.
} 
pasal 14 Undang-undang Nomor 2 Tahun 2002, salah satu kewenangan pejabat kepolisian di bidang proses hukum adalah mengadakan tindakan lain menurut hukum yang bertanggung jawab. Tindakan lain yang dimaksud adalah tindakan penyelidikan dan penyidikan yang dilaksanakan jika memenuhi syarat sebagai berikut:

a. Tidak bertentangan dengan suatu aturaan hukum

Artinya berjalan sesuai dengan hukum positif maupun hukum lainnya yang berlaku ditempat dimana Diskresi kepolisian diambil oleh seorang petugas. Dalam system hukum di Indonesia dikenal 4 (empat) macam sumber hukum antara lain adalah hukum negara atau hukum positif, hukum adat istiadat, hukum agama dan kebiasaan-kebiasaan

b. selaras dengan kewajiban hukum yang mengharuskan tindakan tersebut dilakukan

Artinya tindakan yang dimbil diatur dalam aturan tertentu sebagai suatu kewajiban hukum untuk wajib ditegakkan.

c. harus patut, masuk akal, dan termasuk dalam lingkungann jabatannya

Artinya dapat diterima dengan akal yang sehat bagi lingkungan dimana tindakan itu diambil.

d. pertimbangan yang layak berdasarkan keadaan yaang memaksa

Artinya pada pelaksanaannya atau cara penyampaian dilapangan dilakukan berdasarkan kejadian yang hanya pada saat-saat tertentu (emergencies) tanpa pengamatan ataupun penelitian yang mendalam tentang apa yang diputuskannya tersebut.

e. menghormati HAM

Artinya sesuai dengan ketentuan HAM dan tidak melanggar ketentuan HAM tersebut. ${ }^{11}$

Kepolisian memiliki kewenangan yang terbagi menjadi dua tipe wewenang yang meliputi wewenang umum dan wewenang khusus:

a. Wewenang umum sebagaimana diatur dalam pasal 15 ayat 1 seperti: menerima laporan dan/atau pengaduan, membantu menyelesaikan perselisihan warga masyarakat yang dapat mengganggu ketertiban umum.

b. Wewenang khusus terdapat dua penggolongan yaitu kewenangan yang berdasarkan peraturan perundang-undangan pasal 15 ayat (2) bahwa “Kepolisian Negara Republik Indonesia sesuai dengan peraturan Perundang-undangan lainnya berwenang melaksanakan kewenangan lain yang termasuk dalam lingkup tugas kepolisian.", serta wewenang penyelidikan atau penyidikan dalam proses pidana yang diaur dalam pasal 16 ayat (1) Undang-undang Nomor 2 Tahun 2002 yang berbunyi : Dalam rangka menjalankan tugas sebagaimana dimaksud dalam pasal 13 da 14 di bidang proses pidana, kepolisian Negara Republik Indonesia berwenang untuk :

a. Melakukan penangkapan, penahanan, penggeledahan dan penyitaan.

b. Melarang setiap orang meninggalkan atau memasuki tempat kejadian perkara untuk kepentingan penyidikan.

c. Membawa dan menghadapkan orang kepada penyidik dalam rangka penyidikan.

${ }^{11}$ Ibid. 
d. Menyuruh berhenti orang yang dicurigai dan menanyakan serta memeriksa tanda pengenal diri

e. Melakukan pemeriksaan dan penyitaan

f. Memangiil orang untuk didengar dan diperiksa sebagai tersangka atau sanksi

g. Mendatangkan orang ahli yang diperlukan dalam hubungannya dengan pemeriksaaan perkara

h. Melakukan penghentian penyidikan

i. Menyerahkan berkas perkara kepada penuntut umum

j. Mengajukan permintaan secara langsung kepada pejabat imigrasi yang berwenang ditempat pemeriksaan imigrasi dalam keadaan mendesak atau mendadak untuk mencegah atau menangkal orang yang disangka melakukan tindak pidana.

k. Memberi petunjuk dan bantuan penyidikan kepada penyidik pegawai negeri sipil serta menerima hasil penyidikan penyidik pegawai negeri sipil untuk diserahkan kepada penuntut umum

1. Mengadakan tindakan lain menurut hukum yang bertanggung jawab

m. Dalam Pasal 16 ayat (1) huruf a Undang-Undang Nomor 2 Tahun 2002 disebutkan bawa Kepolisian berwenang untuk melakukan beberapa tindakan yang digunakan untuk mendukung pelaksanaan tugas-tugas pokok Kepolisian yaitu: melakukan penangkapan, penahanan, penggeledahan, dan penyitaan.

n. Kewenangan penangkapan yang dimiliki oleh Kepolisian Negara Republik Indonesia sesuai dengan yang diamanatkan Pasal 16 ayat (1) huruf a yang menyebutkan bahwa yang memiliki kewenangan untuk melakukan penangkapan adalah Kepolisian Negara Republik Indonesia.

o. Hal tersebut mengingatkan bahwa, wewenang Kepolisian Negara Republik Indonesia yang juga disebutkan oleh Pasal 5 ayat (1) huruf b KUHAP, menyatakan bahwa penangkapan yang dilakukan oleh penyelidik merupakan perintah dari penyidik. Disini menekakan bahwa ada Pejabat dari Kepolisian yang memiliki tugas dan kewenangan berbeda. Ini menimbulkan adanya suatu ketidaksinkronan atau ketidak jelasan dalam Undang-Undang Kepolisian yang disebutkan dalam Pasal 16 ayat (1) huruf a mengenai penyebutan Kepolisian Negara Republik Indonesia yang memiliki wewenang untuk melaksanakan penangkapan.

p. Pasal 7 ayat (1) huruf d yang menyatakan bahwa penyidik yang karena kewajibannya memiliki wewenang melakukan penangkapan, penahanan, penggeledahan dan penyitaan. Dari Pasal 7 ayat (1) huruf d ini dikaitkan dengan kewenangan penangkapan, yang juga merujuk pada Pasal 5 ayat (1) huruf b dan ayat (2) menegaskan bahwa adanya perbedaan kewenangan Pejabat Kepolisian Negara Republik Indonesia dalam hal kewenangan melakukan penangkapan.

Diskresi kepolisian di Indonesia secara yuridis diatur dalam Undang-Undang Nomor 2 Tahun 2002 tentang Kepolisian Republik Indonesia, khususnya dalam Pasal 18 ayat (1) yang mengatur bahwa untuk kepentingan umum pejabat kepolisian dalam melaksanakan tugas dan wewenangnya dapat bertindak menurut penilainnya sendiri dan hanya dapat dilakukan dalam keadaan yang sangat perlu dengan memperhatikan peraturan perundang-undangan, serta Kode Etik Kepolisian. Adapun yang dimaksud dengan "bertindak menurut penilaiannya sendiri" adalah suatu tindakan yang dapat dilakukan 
oleh anggota kepolisian yang dalam bertindak harus mempertimbangkan manfaat serta resiko dari tindakannya dan betul-betul untuk kepentingan umum.

Pemahaman Pasal 18 ayat (1) harus dikaitkan dengan konsekuensi pembinaan profesi yang diatur dalam pasal 31, 32, dan 33 Undang-Undang Nomor 2 Tahun 2002, sehingga setiap pejabat Kepolisian Negara Republik Indonesia akan mampu mengambil tindakan secara tepat dan profesional berdasarkan penilaiannya sendiri dalam rangka pelaksanaan tugasnya. Rumusan dalam pasal 18 ayat (2) merupakan batasan bagi pelaksanaan "diskresi" sebagaimana dimaksud pada ayat (1) yaitu selain asas keperluan, tindakan diskresi tetap harus sesuai dan memperhatikan peraturan perundang-undangan serta kode etik profesi Kepolisian Kepolisian Negara Republik Indonesia. Pasal 31, 32, dan 33 Undang-Undang Nomor 2 Tahun 2002 menyatakan bahwa setiap pejabat Kepolisian Negara Republik Indonesia dalam melaksanakan tugas dan wewenangnya harus memiliki kemampuan profesi. Pembinaan kemampuan profesi pejabat kepolisian tersebut diselenggarakan melalui pembinaan etika profesi dan pengembangan pengetahuan serta pengalamannya di bidang teknis kepolisian melalui pendidikan, pelatihan dan penugasan secara berjenjang dan berlanjut.

Untuk mencegah tindakan sewenang-wenang atau arogansi petugas tersebut yang didasarkan atas kemampuan atau pertimbangan subyektif, menurut buku pedoman pelaksanaan tugas bintara polisi maka tindakan diskresi oleh polisi dibatasi oleh :

1. Asas Keperluan, bahwa tindakan itu harus benar-benar diperlukan

2. Tindakan yang diambil benar-benar untuk kepentigan tugas kepolisian.

3. Asas Tujuan, bahwa tindakan yang paling tepat untuk meniadakan suau gangguan atau tidak terjadinya suatu kekhawatiran terhadap akibat yang lebih besar

4. Asas keseimbangan, bahwa dalam mengambil tindakan harus diperhitungkan keseimbangan antara sifat tindakan atau sasaran yang digunakan dengan besar kecilnya gangguan atau berat ringannya suatu obyek yang harus ditindak. ${ }^{12}$

\section{KEWENANGAN POLISI DALAM PEMBERANTASAN NARKOTIKA MENURUT UNDANG-UNDANG NARKOTIKA}

Penyalagunaan Narkotika merupakan salah satu perbuatan melawan hukum yang terjadi adalah dengan melanggar pasal 1 butir 15 Undang-Undang Nomor 35 Tahun 2009 tentang Narkotika (yang selanjutnya disebut dengan UU Narkotika) yaitu dalam pasal tersebut menjelaskan bahwa penyalahguna Narkotika adalah orang yang menggunakan Narkotika tanpa hak atau melawan hukum. UU Narkotika adalah Lex specialis dari Kitab Undang-undang Hukum Acara Pidana yaitu penyalahgunaan narkotika merupakan suatu tindak pidana khusus yang pengaturannya dipisahkan dari KUHAP.

Tindak pidana narkotika yang diatur dalam Undang-undang Narkotika berlaku dengan mempertimbangkan aspek yuridis, folosofis dan sosiologis.. Dalam Undangundang Narkotika yang mengatur mengenai suatu "Extra Ordinary Crime"dengan macam modus operandi, aparat penegak dan sanksinya banyak memiliki implikasi dalam menegakan apa yang tertulis dalam Undang-Undang narkotika.

${ }^{12}$ http://kilometer25.blogspot.com/2012/10/diskresi-kepolisian.html diakses pada 27 Juli 2018 pukul 8.40 
Ketentuan pidana narkotika (bentuk tindak pidana yang dilakukan serta ancaman sanksi pidana bagi pelakunya), diatur dalam UU Narkotika yang tercantum ke dalam lebih dari 30 pasal, yaitu pasal 111 - pasal 142 UU Narkotika. Berdasarkan UU Narkotika, kewenangan polisi dalam pemberantasan tindak pidana narkotika adalah melakukan penyidikan terhadap penyalahgunaan dan peredaran gelap Narkotika dan Prekursor Narkotika berdasarkan UU Narkotika, apabila penyidikan tindak pidana narkotika dilakukan oleh BNN, maka polisi berwenang menerima pemberitahuan secara tertulis dari penyidik BNN tentang dimulaianya penyidikan, berkoordinasi dengan penyidik pegawai negeri sipil tertentu dan penyidik BNN dalam melakukan penyidikan terhadap penyalahgunaan Narkotika dan Prekursor Narkotika, berwenang melakukan "penyadapan" yaitu kegiatan atau serangkaian kegiatan penyelidikan dan/atau penyidikan yang dilakukan oleh penyidik BNN atau Penyidik Kepolisian Negara Republik Indonesia dengan cara menggunakan alat-alat elektronik sesuai dengan kemajuan teknologi terhadap pembicaraan dan/atau pengiriman pesan melalui telepon atau alat komunikasi elektronik lainnya. Berwenang melakukan penyitaan Narkotika dan Prekursor Narkotika, dan selanjutnya wajib melakukan penyegelan dan membuat berita acara penyitaan pada hari penyitaan dilakukan, yang sekurang-kurangnya memuat: a. nama, jenis, sifat, dan jumlah; b. keterangan mengenai tempat, jam, hari, tanggal, bulan, dan tahun dilakukan penyitaan; c. keterangan mengenai pemilik atau yang menguasai Narkotika dan Prekursor Narkotika; dan d. tanda tangan dan identitas lengkap penyidik yang melakukan penyitaan, wajib memberitahukan penyitaan yang dilakukannya kepada kepala kejaksaan negeri setempat dalam waktu paling lama $3 \times 24$ (tiga kali dua puluh empat) jam sejak dilakukan penyitaan dan tembusannya disampaikan kepada ketua pengadilan negeri setempat, Menteri, dan Kepala Badan Pengawas Obat dan Makanan. Menerima penyerahan barang sitaan tersebut beserta berita acaranya jika yang melakukan penyitaan terhadap Narkotika dan Prekursor Narkotika adalah Penyidik pegawai negeri sipil tertentu, dalam waktu paling lama 3 × 24 (tiga kali dua puluh empat) jam sejak dilakukan penyitaan dan tembusan berita acaranya disampaikan kepada kepala kejaksaan negeri setempat, ketua pengadilan negeri setempat, Menteri, dan Kepala Badan Pengawas Obat dan Makanan. Penyerahan barang sitaan tersebut dapat dilakukan dalam waktu paling lama 14 (empat belas) hari jika berkaitan dengan daerah yang sulit terjangkau karena faktor geografis atau transportasi. Untuk keperluan penyidikan, penuntutan, dan pemeriksaan di sidang pengadilan, penyidik Kepolisian Negara Republik Indonesia, penyidik BNN, dan penyidik pegawai negeri sipil menyisihkan sebagian kecil barang sitaan Narkotika dan Prekursor Narkotika untuk dijadikan sampel guna pengujian di laboratorium tertentu dan dilaksanakan dalam waktu paling lama $3 \mathrm{x}$ 24 (tiga kali dua puluh empat) jam sejak dilakukan penyitaan. Ketentuan lebih lanjut mengenai syarat dan tata cara pengambilan dan pengujian sampel di laboratorium tertentu diatur dengan Peraturan Pemerintah. Kepala kejaksaan negeri setempat setelah menerima pemberitahuan tentang penyitaan barang Narkotika dan Prekursor Narkotika dari penyidik Kepolisian Negara Republik Indonesia atau penyidik BNN, dalam waktu paling lama 7 (tujuh) hari wajib menetapkan status barang sitaan Narkotika dan Prekursor Narkotika tersebut untuk kepentingan pembuktian perkara, kepentingan pengembangan ilmu pengetahuan dan teknologi, kepentingan pendidikan dan pelatihan, 
dan/atau dimusnahkan. Barang sitaan Narkotika dan Prekursor Narkotika yang berada dalam penyimpanan dan pengamanan penyidik yang telah ditetapkan untuk dimusnahkan, wajib dimusnahkan dalam waktu paling lama 7 (tujuh) hari terhitung sejak menerima penetapan pemusnahan dari kepala kejaksaan negeri setempat. Penyidik wajib membuat berita acara pemusnahan dalam waktu paling lama 1 × 24 (satu kali dua puluh empat) jam sejak pemusnahan tersebut dilakukan dan menyerahkan berita acara tersebut kepada penyidik BNN atau penyidik Kepolisian Negara Republik Indonesia setempat dan tembusan berita acaranya disampaikan kepada kepala kejaksaan negeri setempat, ketua pengadilan negeri setempat, Menteri, dan Kepala Badan Pengawas Obat dan Makanan. Dalam keadaan tertentu, batas waktu pemusnahan sebagaimana dimaksud pada ayat (2) dapat diperpanjang 1 (satu) kali untuk jangka waktu yang sama. (5) Pemusnahan barang sitaan sebagaimana dimaksud pada ayat (2) dilaksanakan berdasarkan ketentuan.

Barang sitaan untuk kepentingan pengembangan ilmu pengetahuan dan teknologi diserahkan kepada Menteri dan untuk kepentingan pendidikan dan pelatihan diserahkan kepada Kepala BNN dan Kepala Kepolisian Negara Republik Indonesia dalam waktu paling lama 5 (lima) hari terhitung sejak menerima penetapan dari kepala kejaksaan negeri setempat. Kepala BNN dan Kepala Kepolisian Negara Republik Indonesia sebagaimana dimaksud pada ayat (6) menyampaikan laporan kepada Menteri mengenai penggunaan barang sitaan untuk kepentingan pendidikan dan pelatihan.

Penyidik Kepolisian Negara Republik Indonesia dan penyidik BNN wajib memusnahkan tanaman Narkotika yang ditemukan dalam waktu paling lama 2 × 24 (dua kali dua puluh empat) jam sejak saat ditemukan, setelah disisihkan sebagian kecil untuk kepentingan penyidikan, penuntutan, pemeriksaan di sidang pengadilan, dan dapat disisihkan untuk kepentingan pengembangan ilmu pengetahuan dan teknologi, serta untuk kepentingan pendidikan dan pelatihan. Untuk tanaman Narkotika yang karena jumlahnya dan daerah yang sulit terjangkau karena faktor geografis atau transportasi, pemusnahan dilakukan dalam waktu paling lama 14 (empat belas) hari13. Pemusnahan dan penyisihan sebagian tanaman Narkotika sebagaimana dimaksud pada ayat (1) dilakukan dengan pembuatan berita acara yang sekurang-kurangnya memuat:

a. nama, jenis, sifat, dan jumlah;

b. keterangan mengenai tempat, jam, hari, tanggal, bulan, dan tahun ditemukan dan dilakukan pemusnahan;

c. keterangan mengenai pemilik atau yang menguasai tanaman Narkotika; dan

d. tanda tangan dan identitas lengkap pelaksana dan pejabat atau pihak terkait lainnya yang menyaksikan pemusnahan.

Sebagian kecil tanaman Narkotika yang tidak dimusnahkan sebagaimana dimaksud pada ayat (1) disimpan oleh penyidik untuk kepentingan pembuktian. Sebagian kecil tanaman Narkotika yang tidak dimusnahkan sebagaimana dimaksud pada ayat (1) disimpan oleh Menteri dan Badan Pengawas Obat dan Makanan untuk kepentingan

${ }^{13}$ Ketentuan ini menegaskan bahwa jangka waktu 14 (empat belas) hari dimaksudkan agar penyidik Kepolisian Negara Republik Indonesia yang bertugas di daerah yang letak geografisnya dan transportasinya sulit dicapai dapat melaksanakan tugas pemusnahan Narkotika yang ditemukan dengan sebaik-baiknya karena pelanggaran terhadap jangka waktu ini dapat dikenakan pidana. 
pengembangan ilmu pengetahuan dan teknologi. Sebagian kecil tanaman Narkotika yang tidakdimusnahkan sebagaimana dimaksud pada ayat (1) disimpan oleh BNN untuk kepentingan pendidikan dan pelatihan.

Penyidik pegawai negeri sipil yang secara melawan hukum tidak melaksanakan ketentuan sebagaimana dimaksud dalam Pasal 88 dan Pasal 89 dipidana dengan pidana penjara paling singkat 1 (satu) tahun dan paling lama 10 (sepuluh) tahun dan pidana denda paling sedikit Rp100.000.000,00 (seratus juta rupiah) dan paling banyak Rp1.000.000.000,00 (satu miliar rupiah). Penyidik Kepolisian Negara Republik Indonesia dan penyidik BNN yang tidak melaksanakan ketentuan sebagaimana dimaksud dalam Pasal 87, Pasal 89, Pasal 90, Pasal 91 ayat (2) dan ayat (3), dan Pasal 92 ayat (1), ayat (2), ayat (3), dan ayat (4) dikenai pidana penjara paling singkat 1 (satu) tahun dan paling lama 10 (sepuluh) tahun dan pidana denda paling sedikit Rp100.000.000,00 (seratus juta rupiah) dan paling banyak Rp1.000.000.000,00 (satu miliar rupiah).

\section{PERWUJUDAN DISKRESI POLISI PADA UPAYA PEMBERANTASAN TINDAK PIDANA NARKOTIKA DI POLRES BLITAR KOTA}

Perwujudan diskresi dalam rangka pelaksanaan penyelidikan guna mengungkap pelaku tindak pidana penyalahgunaan narkoba beserta jaringannya, telah diatur dalam hukum positif di Indonesia. Adanya substansi hukum menjadi landasan dan syaratsyarat legitimasi bagi implementasi legalitas hukum khususnya bagi Kepolisian dalam pelaksanaan kewenangan diskresi Kepolisian. Adanya substansi hukum yang memadai, dapat memberikan dukungan bagi penyelidik pada Polres Blitar Kota untuk menerapkan diskresi dalam rangka pelaksanaan penyelidikan guna mengungkap pelaku tindak pidana penyalahgunaan narkotika beserta jaringannya.

Berikut data rekapitulasi ungkap kasus tindak pidana narkoba di Polres dan Polsek Blitar Kota Tahun 2017:

\begin{tabular}{|c|c|c|c|c|c|c|c|c|}
\hline $\begin{array}{l}\mathrm{N} \\
\mathrm{O}\end{array}$ & $\begin{array}{c}\text { NAMA DAN } \\
\text { IDENTITAS } \\
\text { TERSANGKA }\end{array}$ & $\begin{array}{c}\text { NOMO } \\
\text { R } \\
\text { LAPOR } \\
\text { AN } \\
\text { POLISI }\end{array}$ & $\begin{array}{l}\text { WAKTU } \\
\text { DAN TKP }\end{array}$ & $\begin{array}{l}\mathrm{UM} \\
\mathrm{UR} \\
/ \mathrm{T} \\
\mathrm{H}\end{array}$ & $\begin{array}{c}\text { PENDIDIK } \\
\text { AN }\end{array}$ & $\begin{array}{c}\text { PEKERJA } \\
\text { AN }\end{array}$ & $\begin{array}{c}\text { BARAN } \\
\text { G } \\
\text { BUKTI }\end{array}$ & $\begin{array}{c}\text { MODUS } \\
\text { OPERANDI }\end{array}$ \\
\hline 1 & 2 & 3 & 4 & 5 & 6 & 7 & 8 & 9 \\
\hline 1 & 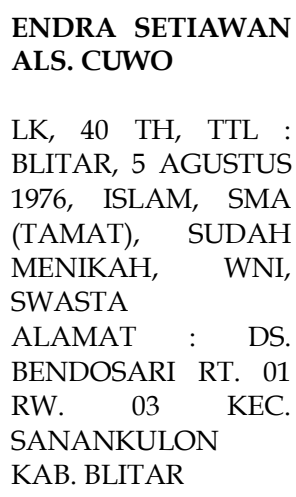 & $\begin{array}{l}\text { K/LP/1 } \\
\text { /I/2017 } \\
/ \\
\text { JATIM/ } \\
\text { RESTA } \\
\text { BLITAR } \\
\text { TGL. } 1 \\
\text { JANUA } \\
\text { RI } 2017\end{array}$ & $\begin{array}{l}\text { HARI : } \\
\text { SABTU } \\
\text { TGL : } 31 \\
\text { DESEMBER } \\
2016 \quad \\
\text { PUKUL : } \\
22.15 \quad \text { WIB } \\
\text { TKP : LAP. } \\
\text { DS. } \\
\text { TANJUNGS } \\
\text { ARI KEC. } \\
\text { SUKOREJO } \\
\text { KOTA } \\
\text { BLITAR }\end{array}$ & 40 & $\begin{array}{c}\text { SMA } \\
\text { (TAMAT) }\end{array}$ & $\begin{array}{l}\text { SWAST } \\
\text { A }\end{array}$ & $\begin{array}{ll}\bullet \quad 1,07 \\
\text { GRAM } \\
\text { SABU } \\
\bullet & \\
\text { BUAH } & \\
\text { BUPET } & \\
\text { KACA } & \end{array}$ & $\begin{array}{l}\text { TERSANGKA } \\
\text { DIDUGA } \\
\text { MENYALAHGUN } \\
\text { AKAN } \\
\text { MENGEDARKAN } \\
\text { NARKOTIKA } \\
\text { (SABU) DENGAN } \\
\text { CARA } \\
\text { MENJUALNYA }\end{array}$ \\
\hline 2 & $\begin{array}{l}\text { ARI WIRYAWAN } \\
\text { ALS. MACAN } \\
\text { LK, } 43 \mathrm{TH}, \text { ISLAM, }\end{array}$ & $\begin{array}{l}\text { K/LP/2 } \\
55 / X I I / \\
2016 / \\
\text { JATIM/ }\end{array}$ & $\begin{array}{ll}\text { HARI } & : \\
\text { JUMAT } & \\
\text { TGL }: & 6 \\
\text { JANUARI } & \end{array}$ & 43 & $\begin{array}{c}\text { SMA } \\
\text { (TAMAT) }\end{array}$ & $\begin{array}{l}\text { SWAST } \\
\text { A }\end{array}$ & 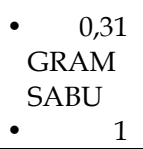 & $\begin{array}{l}\text { TERSANGKA } \\
\text { DIDUGA } \\
\text { MENYALAHGUN } \\
\text { A KAN / }\end{array}$ \\
\hline
\end{tabular}




\begin{tabular}{|c|c|c|c|c|c|c|c|c|}
\hline & $\begin{array}{lr}\text { SMA } & \text { (TAMAT), } \\
\text { SUDAH } & \text { MENIKAH, } \\
\text { WNI, } & \text { SWASTA } \\
\text { ALAMAT } & : \quad \text { DS. } \\
\text { JIWUT RT. } & \text { 02 RW. } 07 \\
\text { KEC. } & \text { NGLEGOK } \\
\text { KAB. BLITAR }\end{array}$ & $\begin{array}{l}\text { RESTA } \\
\text { BLITAR } \\
\text { TGL. 2 } \\
\text { DESEM } \\
\text { BER } \\
2016\end{array}$ & 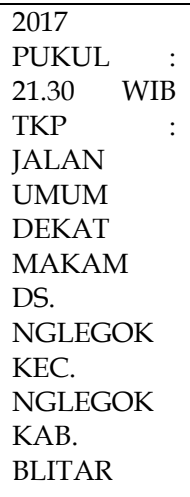 & & & & $\begin{array}{l}\text { BUAH } \\
\text { HP } \\
\text { MERE } \\
\text { K } \\
\text { NOKI } \\
\text { A }\end{array}$ & $\begin{array}{l}\text { MENGEDARKAN } \\
\text { NARKOTIKA } \\
\text { (SABU) DENGAN } \\
\text { CARA } \\
\text { MENJUALNYA }\end{array}$ \\
\hline 3 & 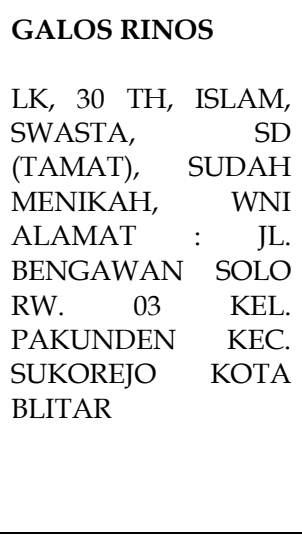 & $\begin{array}{l}\text { K/LP/2 } \\
\text { /I/2017 } \\
\text { / } \\
\text { JATIM/ } \\
\text { RESTA } \\
\text { BLITAR } \\
\text { TGL. } 12 \\
\text { JANUA } \\
\text { RI } 2017\end{array}$ & $\begin{array}{l}\text { HARI } \\
\text { SELASA } \\
\text { TGL : } 12 \\
\text { JANUARI } \\
2017 \\
\text { PUKUL : } \\
12.30 \text { WIB } \\
\text { TKP : } \\
\text { LAPANGA } \\
\text { N DS. } \\
\text { GHENENG } \\
\text { AN KEC. } \\
\text { SANANKUL } \\
\text { ON KAB. } \\
\text { BLITAR } \\
\end{array}$ & 30 & $\begin{array}{c}\text { SD } \\
\text { (TAMAT) }\end{array}$ & $\begin{array}{l}\text { SWAST } \\
\text { A }\end{array}$ & $\begin{array}{l}\bullet \text { 0, } 33 \\
\text { GRAM } \\
\text { SABU } \\
-1 \\
\text { BUAH } \\
\text { HP } \\
\text { SAMSU } \\
\text { NG }\end{array}$ & $\begin{array}{l}\text { TERSANGKA } \\
\text { DIDUGA } \\
\text { MENGEDARKAN } \\
/ \\
\text { MENYALAHGUN } \\
\text { A KAN } \\
\text { NARKOTIKA } \\
\text { (SABU-SABU) } \\
\text { DENGAN CARA } \\
\text { MENJUALNYA }\end{array}$ \\
\hline 4 & $\begin{array}{l}\text { AGUS WIBOWO } \\
\text { LK, } 42 \text { TH, TTL : } \\
\text { BLITAR 1 AGUSTUS } \\
\text { 1974, ISLAM, SUDAH } \\
\text { MENIKAH, PNS } \\
\text { KOTA BLITAR, WNI } \\
\text { ALAMAT : JL. } \\
\text { BAKUNG NO. } 2 \text { RT. } \\
\text { 03 RW. 06 KEL. } \\
\text { SUKOREJO KEC. } \\
\text { SUKOREJO KOTA } \\
\text { BLITAR }\end{array}$ & $\begin{array}{l}\text { K/LP/3 } \\
\text { /I/ } \\
\text { 2016/JA } \\
\text { TIM/ } \\
\text { RESTA } \\
\text { BLITAR } \\
\text { TGL. 23 } \\
\text { JANUA } \\
\text { RI 2016 }\end{array}$ & $\begin{array}{l}\text { HARI : } \\
\text { SENIN } \\
\text { TGL : } 23 \\
\text { JANUARI } \\
2016 \\
\text { PUKUL : } \\
12.30 \text { WIB } \\
\text { TKP : DI } \\
\text { DALAM } \\
\text { RUMAH DI } \\
: \quad \text { JL. } \\
\text { BAKUNG } \\
\text { NO. 2 RT. 03 } \\
\text { RW. 06 KEL. } \\
\text { SUKOREJO } \\
\text { KEC. } \\
\text { SUKOREJO } \\
\text { KOTA } \\
\text { BLITAR }\end{array}$ & 42 & $\begin{array}{c}\text { SMP } \\
\text { (TAMAT) }\end{array}$ & $\begin{array}{l}\text { SWAST } \\
\text { A }\end{array}$ & $\begin{array}{l}\bullet \text { } 0,24 \\
\text { GRAM } \\
\text { SABU } \\
\bullet 1 \\
\text { BUAH } \\
\text { HP } \\
\text { NOKIA }\end{array}$ & $\begin{array}{l}\text { TERSANGKA } \\
\text { DIDUGA } \\
\text { MENYALAHGUN } \\
\text { A KAN / } \\
\text { MENGEDARKAN } \\
\text { SABU DENGAN } \\
\text { CARA } \\
\text { MENJUALNYA }\end{array}$ \\
\hline 5 & 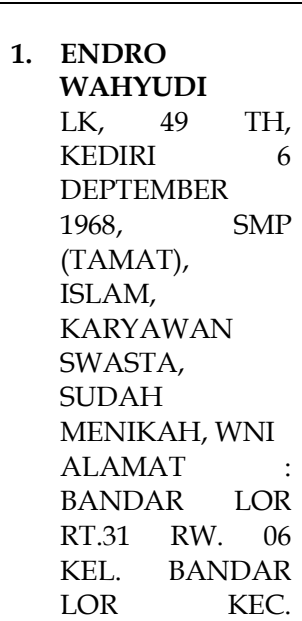 & $\begin{array}{l}\text { K/LP/04 } \\
\text { /I/2017/ } \\
\text { JATIM/ } \\
\text { RESTA } \\
\text { BLITAR } \\
\text { TGL. 24 } \\
\text { JANUARI } \\
2016\end{array}$ & $\begin{array}{l}\text { HARI : } \\
\text { SENIN } \\
\text { TGL : 23 } \\
\text { JANUARI } \\
2016 \\
\text { PUKUL : } \\
21.30 \text { WIB } \\
\text { TKP : } \\
\text { TIMUR POS } \\
\text { POLISI } \\
\text { PASAR } \\
\text { PATOK } \\
\text { KEC. } \\
\text { PONGGOK } \\
\text { KAB } \\
\text { BLITAR }\end{array}$ & 49 & $\begin{array}{c}\text { SMP } \\
\text { (TAMAT) }\end{array}$ & $\begin{array}{r}\text { SWAST } \\
\text { A }\end{array}$ & $\begin{array}{l}\text { - } 0,93 \\
\text { GRAM } \\
\text { SABU- } \\
\text { SABU } \\
\text { - } 2 \text { BUAH } \\
\text { HP } \\
\text { - } 2 \text { BUAH } \\
\text { PIPET } \\
\text { - } 1 \text { BUAH } \\
\text { BUKU } \\
\text { TABUN } \\
\text { GAN } \\
\text { BCA } \\
\text { A.N. } \\
\text { DAMAR } \\
\text { OCH }\end{array}$ & $\begin{array}{l}\text { TERSANGKA } \\
\text { DIDUGA } \\
\text { MENGEDARKAN } \\
\text { / } \\
\text { MENYALAHGUN } \\
\text { A KAN } \\
\text { NARKOTIKA } \\
\text { (SABU-SABU) } \\
\text { DENGAN CARA } \\
\text { MENJUALNYA }\end{array}$ \\
\hline
\end{tabular}




\begin{tabular}{|c|c|c|c|c|c|c|c|c|}
\hline & $\begin{array}{l}\text { MOJOROTO } \\
\text { KOTA KEDIRI } \\
\text { 2. } \text { DAMAROCH } \\
\text { KRIDO } \\
\text { SANTOSO } \\
\text { LK, } 50 \quad \text { TH, } \\
\text { YOGYKARTA } 3 \\
\text { MARET } \\
\text { 1967,SMA } \\
\text { (TAMAT), ISLAM } \\
\text { WIRASWASTA, } \\
\text { SUDAH } \\
\text { MENIKAH, WNI } \\
\text { ALAMAT } \\
\text { SANGKRAH RT. } \\
\text { 01 RW. 06 KEL. } \\
\text { SANGKRAH } \\
\text { KEC. PASAR } \\
\text { KLIWON KOTA } \\
\text { SURAKARTA }\end{array}$ & & & & & & & \\
\hline \multicolumn{9}{|c|}{ JUNI } \\
\hline 1 & $\begin{array}{l}\text { AGUS MULYANTO } \\
\text { ALS. GAMBLEH BIN } \\
\text { MULYADI } \\
\text { LK, } 27 \text { TH, ISLAM, } \\
\text { MALANG } 10 \text { APRIL } \\
\text { 1990, SD (TAMAT), } \\
\text { SUDAH MENIKAH, } \\
\text { WNI, SWASTA } \\
\text { ALAMAT : DSN. } \\
\text { MENTRAMAN RT. } \\
\text { 40 RW. 09 DS. } \\
\text { JATIGUWI KEC. } \\
\text { SUMBERPUCUNG } \\
\text { KAB. MALANG }\end{array}$ & $\begin{array}{l}\mathrm{K} / \mathrm{LP} / 2 \\
\text { 9/V/20 } \\
17 \\
\text { /JATIM } \\
\text { /RESTA } \\
\text { BLITAR } \\
\text { TGL } 4 \\
\text { MEI } \\
2017\end{array}$ & $\begin{array}{l}\text { HARI } \\
\text { KAMIS } \\
\text { TGL. : } 4 \text { MEI } \\
2017 \\
\text { PUKUL : } \\
23.00 \text { WIB } \\
\text { WIB } \\
\text { TKP : JL. } \\
\text { P.SUDIRMA } \\
\text { N KOTA } \\
\text { BLITAR }\end{array}$ & 27 & $\begin{array}{c}\text { SD } \\
\text { (TAMAT) }\end{array}$ & $\begin{array}{c}\text { SWAST } \\
\text { A }\end{array}$ & $\begin{array}{l}\bullet 0,26 \\
\text { GRAM } \\
\text { SABU- } \\
\text { SABU } \\
\bullet 1 \text { BUAH } \\
\text { HP } \\
\text { SAMSU } \\
\text { NG }\end{array}$ & $\begin{array}{l}\text { TERSANGKA } \\
\text { DIDUGA } \\
\text { MENYALAHGUN } \\
\text { A KAN / } \\
\text { MENGEDARKAN } \\
\text { NARKOTIKA } \\
\text { JENIS SABU } \\
\text { DENGAN CARA } \\
\text { MENJUALNYA }\end{array}$ \\
\hline 2 & $\begin{array}{l}\text { WARAS HARSONO } \\
\text { BIN ALM. } \\
\text { SOETJIPTO ABDUL } \\
\text { RAHMAN } \\
\text { LK, } 51 \text { TH, ISLAM, } \\
\text { T.AGUNG } 2 \\
\text { PEBRUARI 1966, } \\
\text { SWASTA, S.1, } \\
\text { SUDAH MENIKAH, } \\
\text { WNI } \\
\text { ALAMAT : DS. } \\
\text { PAKISREJO RT. } 04 \\
\text { RW. 01 KEC. } \\
\text { REJOTANGAN KAB. } \\
\text { TULUNGAGUNG }\end{array}$ & $\begin{array}{l}\mathrm{K} / \mathrm{LP} / 3 \\
4 / \mathrm{V} / 20 \\
17 \\
\text { /JATIM } \\
\text { /RESTA } \\
\text { BLITAR } \\
\text { TGL } 17 \\
\text { MEI } \\
2017\end{array}$ & 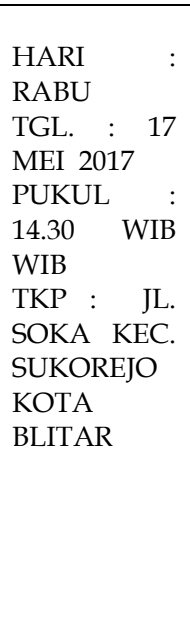 & 51 & S.1 & $\begin{array}{c}\text { SWAST } \\
\text { A }\end{array}$ & $\begin{array}{l}\bullet \text { 0, } 29 \\
\text { GRAM } \\
\text { SABU- } \\
\text { SABU } \\
\text { - } 1 \text { BUAH } \\
\text { HP } \\
\text { SAMSU } \\
\text { NG }\end{array}$ & $\begin{array}{l}\text { TERSANGKA } \\
\text { DIDUGA } \\
\text { MENYALAHGUN } \\
\text { A KAN / } \\
\text { MENGEDARKAN } \\
\text { NARKOTIKA } \\
\text { JENIS SABU } \\
\text { DENGAN CARA } \\
\text { MENJUALNYA }\end{array}$ \\
\hline 3 & $\begin{array}{l}\text { LANGGENG } \\
\text { WIBOWO ALS. IPAL } \\
\text { BIN BONADI } \\
\text { LK, } 17 \text { TH, BLITAR } 20 \\
\text { JULI 1999, ISLAM, } \\
\text { SWASTA, SMP } \\
\text { TAMAT, BELUM } \\
\text { MENIKAH } \\
\text { ALAMAT : DSN. }\end{array}$ & $\begin{array}{l}\mathrm{K} / \mathrm{LP} / 3 \\
\text { 9/V/20 } \\
17 \\
\text { /JATIM } \\
\text { /RESTA } \\
\text { BLITAR } \\
\text { TGL } 31 \\
\text { MEI } \\
2017\end{array}$ & $\begin{array}{l}\text { HARI : } \\
\text { RABU } \\
\text { TGL. : } 31 \\
\text { MEI 2017 } \\
\text { PUKUL : } \\
\text { 16.05 WIB } \\
\text { WIB } \\
\text { TKP : } \\
\text { DEPAN } \\
\text { WARNET }\end{array}$ & 17 & SMP & $\begin{array}{c}\text { SWAST } \\
\text { A }\end{array}$ & $\begin{array}{l}\text { - } 42 \\
\text { BUTIR } \\
\text { PIL } \\
\text { DOBEL } \\
\text { L } \\
\text { - } 1 \text { BUAH } \\
\text { HP } \\
\text { SAMSU } \\
\text { NG } \\
\text { - UANG }\end{array}$ & $\begin{array}{l}\text { TERSANGKA } \\
\text { DIDUGA } \\
\text { MENYALAHGUN } \\
\text { A KAN / } \\
\text { MENGEDARKAN } \\
\text { OBAT KERAS } \\
\text { JENIS PIL DOBEL } \\
\text { L DENGAN CARA } \\
\text { MENJUALNYA }\end{array}$ \\
\hline
\end{tabular}




\begin{tabular}{|l|l|l|l|l|l|l|}
\hline & PACUH DS. & & JL. & & & TUNAI \\
PENATARAN KEC. & & PENATARA & & & & RP. \\
NGLEGOK KAB. & N KEC. & & & $80.000,-$ & \\
BLITAR & NGLEGOK & & & & & \\
& & KAB. & & & & \\
\hline
\end{tabular}

Sumber: Data Sekunder, 2018

Pelaksanaan diskresi harus dilakukan dengan pertimbangan-pertimbangan yang jelas, yang bertujuan untuk menghindari munculnya penilaian negatif dari masyarakat bahwa penerapan diskresi kepolisian dianggap sebagai permainan pihak kepolisian untuk memperoleh keuntungan materi dari pihak-pihak yang berperkara ${ }^{14}$ agar penerapan diskresi kepolisian tidak dipandang sebagai alat rekayasa dari aparat kepolisian untuk memperoleh keuntungan pribadi, maka penerapannya harus dilandasi dasar hukum yang kuat. ${ }^{15}$ Agar penerapan diskresi Kepolisian tidak dipandang sebagai alat rekayasa dari aparat Kepolisian untuk memperoleh keuntungan pribadi (khususnya bagi penyelidik di Polres Blitar Kota), maka penerapannya harus dilandasi dasar hukum yang kuat. Hal ini dapat diimplementasikan oleh Polres Blitar Kota melalui penyelidikan dengan pola khusus, dan ini merupakan "tindakan lain" dari penyelidik untuk kepentingan penyelidikan (diskresi). Dilakukan semata-mata untuk kepentingan umum (khususnya masyarakat di Blitar Kota), mengingat tindak pidana ini sangat berbahaya dan mempunyai trend perkembangan modus operandi yang semakin canggih. Oleh karena itu, Polres Blitar Kota dalam menyikapi kondisi demikian perlu melakukan upaya atau langkah yang bersifat khusus pula untuk menekan, memberantas tindak pidana penyalahgunaan narkotika.

Untuk menerapkan kewenangan diskresi tersebut, pelaksanaan ketentuan ini (tindakan lain-diskresi Kepolisian-) hanya dapat dilaksanakan dalam keadaan yang sangat perlu dengan memperhatikan peraturan perundang-undangan serta kode etik profesi Kepolisian Negara Republik Indonesia. Dalam pelaksanaan diskresi Kepolisian di Polres Blitar Kota tidak untuk memenuhi kepentingan pribadi, kelompok atau organisasi melainkan harus dapat mengakomodir kepentingan umum, keadilan, kemanusiaan yang terjadi pada situasi atau kondisi yang bersifat mendesak serta harus didasari dengan hati nurani, etika profesi dan moral.

Perwujudan Diskresi Polisi pada upaya pemberantasan tindak pidana narkotika di Polres Blitar Kota, dilakukan berdasarkan keputuan anggota polisi di lapangan yang tahu dan paham tentang situasi dan kondisi dimana dia harus berbuat apa dan bagaimana, sehingga diskresi yang terterapkan, lebih berbentuk tindakan diskresi polisi dengan sifat individual. Pada saat melakukan penangkapan di luar daerah atau luar pulau saat surat tugas atau surat perintah penangkapan habis masa berlakunya, disitulah diskresi kepolisian berlaku. Sedangkan tindakan diskresi Kepolisian yang dilakukan oleh anggota Polri yang dalam kapasitasnya mewakili organisasi berpedoman pada suatu hasil dari kebijaksanaan dari birokrasi yang berlaku, hal tersebut dapat melalui suatu pengamatan atau penelitian dan pembahasan yang mendalam tentang apa yang akan diputuskan

${ }^{14} \mathrm{http}: / /$ elisatris.wordpress.com/penerapan-diskresi-kepolisian-dalam penegakan-hukum-hukumpidana/, diakses pada 27 juli 2018 pukul 09.25 
sebagai bentuk tindakan diskresi yang akan dilakukannya sehingga hal tersebut dapat dikatakan sebagai bentuk pengawasannya.

\section{PENUTUP}

Diskresi polisi merupakan tindakan pihak berwenang berdasarkan hukum untuk bertindak pasti atas dasar situasi dan kondisi menurut pertimbangan dan keputusan nuraninya sendiri sesuai peraturan Undang-Undang Nomor 2 Tahun 2002 tentang Kepolisian Republik Indonesia. Atas kewenangan polisi melakukan penyidikan terhadap semua tindak pidana, maka pelaksanaan diskresi harus dilakukan dengan pertimbanganpertimbangan yang jelas, yang bertujuan untuk menghindari munculnya penilaian negatif dari masyarakat bahwa penerapan diskresi kepolisian dianggap sebagai permainan pihak kepolisian untuk memperoleh keuntungan materi dari pihak-pihak yang berperkara agar penerapan diskresi kepolisian tidak dipandang sebagai alat rekayasa dari aparat kepolisian untuk memperoleh keuntungan pribadi, sehingga penerapannya harus dilandasi dasar hukum yang kuat. Terkait hal tersebut, perwujudan Diskresi Polisi di Polres Blitar Kota pada upaya pemberantasan tindak pidana narkotika, bersifat individual dan institusional.

\section{DAFTAR PUSTAKA}

\section{Jurnal dan Buku:}

Kenneth dkk, Police Discretion, West Publishing, Chicago, 1975.

Friedman, Lawrence M., Sistem Hukum Perspektif Ilmu Sosial, Bandung: Nusa Media, 2011.

Kelsen, Hans, Teori Umum tentang Hukum dan Negara, Bandung: Nusa Media, 2011.

Adjie, Habib, Hukum Notaris Indonesia, Tafsir Tematik Terhadap UU No. 30 Tahun 2004 tentang Jabatan Notaris, Bandung : Refika Aditama, 2008.

Tim Penyusun Kamus Pusat Pembinaan dan Pengembangan Bahasa, Kamus Besar Bahasa Indonesia.

Ridwan HR, Hukum Administrasi Negara, Jakarta : PT Raja Grafindo Persada, 2007.

Kementrian Kesehatan RI, Pusat Data dan Informasi, Anti Narkoba Se-Dunia 26 Juni'17, Jakarta: Infodatin, 2017.

Sianturi, E. Y. Kanterdan S. R., Asas Asas Hukum Pidana di Indonesia dan Penerapannya, Storia Gratifika, Jakarta, 2002.

Depdikbud Kamus Besar Bahasa Indonesia, Cet ke-2, Jakarta: Balai Pustaka, 1989.

Prasetyo, Teguh, Hukum Pidana Edisi Revisi, Jakarta: PT Raja Grafindo persada, 2014.

Makarao, Mohammad Taufik dan Suhasril, Hukum Acara Pidana dalam Teori dan Praktek, Jakarta: Ghalia Indonesia, 2004.

Soekanto, Soerjono dan Mamudji, Sri, Penelitian Hukum Normatif Suatu Tinjauan Singkat, Cetakan ke-11, Jakarta: PT Raja Grafindo Persada, 2009.

Marzuki, Peter Mahmud, Penelitian Hukum, Jakarta: Kencana Prenada Media Group, 2009. Ibrahim, Johnny, Metode Penelitian Hukum Normatif, Malang : Bayumedia, 2011.

Puspa, Yan Pramadya, Kamus Hukum, Edisi Lengkap Bahasa Belanda, Indonesia, Inggris, Semarang: CV Aneka Ilmu, 2014. 
JCT Simorangkir, Kamus Hukum, Jakarta: Sinar Grafika, 2002.

Faal, Menghukum Kasus Pidana oleh Polisi Diskriminasi Polisi: Diskriminasi Polisi , Yogyakarta: Pradnya Paramita Press, 1991.

Muchsan, Beberapa Catatan tentang Hukum Administrasi Negara dan Pertimbangan Administratif di Indonesia, Yogyakarta: Liberty, 1981.

Prawira, Putu Yudha, dkk, Jurnal Hukum: Diskresi Kepolisian Dalam Penyelidikan Tindak Pidana Penyalahgunaan Narkoba di Polda Jateng, 2014.

H.R. Abdussalam. Hukum Kepolisian Sebagai Hukum Positif dalam Disiplin Hukum. Jakarta: Restu Agung, 2009.

Sunggono, Bambang, Metodologi Penelitian Hukum, Jakarta: Raja Grafindo Persada, 2005.

Ilham, Bisri, Sistem Hukum Indonesia, Jakarta: Grafindo Persada, 2004.

\section{Peraturan Perundang-Undangan:}

Kitab Undang-Undang Hukum Pidana

Kitab Undang-Undang Hukum Acara Pidana

Undang-Undang Republik Indonesia Nomor 2 Tahun 2002 tentang Kepolisian Negara Kesatuan Republik Indonesia

Undang-Undang Republik Indonesia Nomor 35 Tahun 2009 tentang Narkotika.

Undang-Undang Republik Indonesia Nomor 30 Tahun 2014 tentang Administrasi Pemerintahan.

Peraturan Menteri Kesehatan Republik Indonesia Nomor 2 Tahun 2017 tentang Perubahan Penggolongan Narkotika.

\section{Internet:}

http:/ / elisatris.wordpress.com/penerapan-diskresi-kepolisian-dalam penegakanhukum-hukum-pidana/

https:/ / krisnaptik.com/polri-4/hukum-kepolisian/hukum-kepolisian/.

kasus nenek minah dihukum 1 bulan 15 hari. Mencuri 3 buah kakao. Kamis, 19 November 2009. www.news.detik.com.

http:/ / kilometer25.blogspot.com/2012/10/diskresi-kepolisian.html

Dianaanitakristianti.blogspot.com/2013/12/diskresi-kepolisian.html 